\title{
Legal Awareness-Hubris for Women to Combat Violence
}

\author{
Pravabati Guru \\ Department of Home Science, Government Women's College, Sambalpur, India \\ Email: pravabatiguru@gmail.com
}

Received 27 July 2015; accepted 14 September 2015; published 17 September 2015

Copyright (C 2015 by author and Scientific Research Publishing Inc. This work is licensed under the Creative Commons Attribution International License (CC BY). http://creativecommons.org/licenses/by/4.0/

(c) (i) 0pen Access

\begin{abstract}
Legal awareness is a sine qua non to combat violence against women. India is the first country to introduce the Protection of Women from Domestic Violence Act-2005 and a number of other laws to empower women. "Are women really legally aware" is a critical question. All the national newspapers are embedded with news about violence against women, which include both domestic and professional front. Though Government of India has enacted a number of laws to empower and protect women from violence, these laws are not that effective due to lack of awareness among women of the country. The present study explored the level of legal awareness among women of different professions, education, and income and its impact on their real life as it related to violence. The findings showed that a positive relationship existed between education, income, professional work and legal awareness. It was also observed that legal awareness and victimization of women were inversely related.
\end{abstract}

\section{Keywords}

Women, Violence, Legal Awareness, Education, Income, Profession

\section{Introduction}

The U.N. has explicitly stated, “Access to justice is a basic human right as well as an indispensable means to combat poverty, prevent, and resolve conflict.” The concept that a woman is as much as human being as a man and, thus, entitled to the same freedoms, rights and responsibilities is, yet, to find universal acceptance. This is true in spite of unequivocal assertions that women have complete and equal rights and that the Directive Principles and the Fundamental Duties bestow equal status to women and also provide special protection. Importance of the status of women was a pledge made by the constitution and admitted by the government as one of the major tasks. 
Violence affects the life of millions of women worldwide, in all socio-economic and educational classes. It cuts across cultural and religious barriers, impacting the right of women fully in the society. Violence against women takes a dismaying variety of forms, from domestic abuse and rape to child marriages and female circumcision. All are violations of the most fundamental rights. Webster's dictionary describes "Harassment is the trouble caused by repeated attacks or incursions to disturb personality or torment as with troubles, cares bother continually”. The Protection of Women from Domestic Violence Act-2005 defines violence as any act, omission or commission or conduct of any adult male person of the family, which harms or injures or endangers the health, safety, life, limb or well-being, whether mental or physical of the women or tends to do so and includes causing physical abuse, sexual abuse, verbal and emotional abuse, and economic abuse and harassment or coercion to meet any unlawful demand for any dowry constitutes domestic violence” [1].

Since independence, many laws have been enacted and many have been amended to strengthen the power of women in India. The principles of gender justice are firmly established in the constitution. The Indian Constitution further provides for affirmative action and for positive discrimination by empowering the state to make special provisions for women [2]. The Fundamental Rights, Directive Principles of State Policy, The Special Marriage Act 1954, The Marriage laws (Amendment) Act 1976, Child Marriage (Restraint) Act-1929, Divorce by Mutual consent, Hindu Marriage Act 1955, Dowry Prohibition Act 1961, Indian Penal Code (IPC) like 228A, 294A, 304-B, 306, 354, 376, 376-B are the different laws framed to empower women in India. Women's empowerment may be defined as "a bottom-up process of transforming gender power relations, through individuals or groups developing awareness of women’s subordination and building their capacity to challenge it” [3]-[6]. Women's empowerment does not imply that women take over control previously held by men. Rather, it lies in the need to transform the nature of power relations [4].

Many United Nations (UN) conferences have advocated that women's empowerment is central to sustainable development. The Copenhagen Declaration of the World Summit on Social Development (WSSD) is a case in point. WSSD called for the recognition that empowering people, particularly women, to strengthen their own capacities was a main objective of development and that empowerment required the full participation of people in the formulation, implementation, and evaluation of decisions determining the functioning and well-being of the societies [3].

Though many laws and acts have been instituted in India and steps taken to combat violence against women, the real impetus should be on the effective implementation of these laws and actions. There are a number of laws for protection of women; however, when women are not aware of the legal remedies available, it is unlikely that they can get justice for the violence perpetrated against them [7]. A study conducted by students at Sophia College, Mumbai showed that $50 \%$ of domestic victims were unaware about the laws protecting women from violence [8]. Another study conducted in the state of Madhya Pradesh and Maharashtra showed that battered women were often unaware of their legal rights, and prefered to remain in the abusive relationship [9].

If people are aware of their rights and duties, the delivery of justice in a society becomes much easier. Legal awareness and legal literacy make drastic changes in our democracy. Awareness of laws helps academic professionals as well as the general public to use the legal system more effectively. Only two percent of women in rural areas gain access to justice, even though several laws have been enacted in Parliament protecting them against violence and abuse [10]. Thus, legal awareness among women is vital. Efforts need to be made through formal and informal education to increase women's awareness of legal recourse and their rights to be free from violence.

Objective of the study: The objectives of this study are: 1) to assess the level of legal awareness among women of different professions with different educational and income levels; 2) to examine the relationship between levels of legal awareness and the level of violence inflicted upon them.

\section{Methodology}

\subsection{Data Collection, Scoring and Statistical Analysis}

This study was based on primary data collected using Questionnaire consisting of 200 women of different professions selected by simple random sampling from Sambalpur Town, Odisha, India. The level of harassment and level of legal awareness were studied and questions were framed. Indirect questions related to different laws were asked as a woman may not know which Indian Penal Code (IPC) is related to which particular law, yet, she may know the different aspects of that law. 
A scoring method was used to judge level of legal awareness by respondents. Statistical analysis like mean, range, standard deviation, coefficient of variation and correlation coefficient are applied to reach a conclusion. Responses are framed in scale method, 3 points for yes, 2 points for do not know and 1 for no. A “yes” response means that the woman has knowledge about that law. A "no" response means that the woman is denying awareness of the presence of that law; and "do not know" means that a woman does not have an idea about that particular law, though she may be aware of laws in general about protecting women from violence and abuse. The total score is divided in to three categories 1) 0 - 50 less aware, 2) 50 - 100 moderately aware and 3) 100 - 150 aware.

\subsection{Representative Questionnaire}

A total of Forty one questions were framed related to level of harassment and legal awareness among the women of different professions was assessed. A set of representative questions included as mentioned below:

Q. A daughter has equal right like a brother on her Father's property.

Q. Husband and family members are punishable if a wife died under unnatural circumstances within seven years of marriage.

Q. A boss or colleagues will be legally punished if he shows some physical advances like patting, touching showing physical signs which are sexual.

Q. According to law no one can force a woman for an abortion.

Q. Detection of sex of an unborn child is legally punishable.

Q. A husband is legally punishable if he is torturing wife like beating, kicking, slapping, hitting etc.

Q. Legally a husband cannot torture a wife for not having a male child.

Q. If a husband will forcibly takes away the salary income or wages than he will be punished.

Q. Husbands will be punished by law if he will force a wife for sexual intercourse.

Q. If a husband is having extra marital relationship than the wife can file can file a divorce case against him.

\section{Findings}

\subsection{Profession and Legal Awareness}

Table 1 shows that 3 out of 50 college teachers are moderately aware and 47 are aware of legal protections. Six of 70 school teachers are moderately aware and 64 are aware. Among clerks interviewed, 8 out of 30 are moderately aware and 22 are aware. All the cases of sweepers are less aware of legal protections as all of them have scored less than 50 .

In the present study the means between respondents who have different professions vary considerably. The coefficient of variation is used for the purpose of comparing variability of data. The coefficient of variation is 12.89 of college teachers, 13.8 for school teachers and 19.81 of clerks.

As the standard deviation is 0 for sweepers, so, too, the coefficient of variation is also 0 . The legal awareness range of college teachers, school teachers, clerks and sweepers are 34, 35, 43, and 05 respectively (Table 2).

\subsection{Relationship between Legal Awareness and Number of Abuse}

Table 3 shows the score of legal awareness among women of different professions and its relationship with abuse.

College Teachers: Out of 50 college teachers only 8 are victims of any type of abuse. The scoring shows that out of 50, 3 are moderately aware and 47 are aware of legal protections from violence and abuse. Out of 3 moderately aware, 2 were victims and out of 47 who are aware, 6were victims of any type of harassment.

School Teachers: Out of 70 school teachers, 30 are victims of any type of abuse. According to the scoring formula, of 70 respondents, 6 are moderately aware and 64 are aware of legal protections. Five of 6 respondents who were moderately aware of legal protections and of 64 respondents who stated they were aware of protections, 25 report being victims of any type of abuse.

Clerks: Among 30 clerks, 20 women are victims of any type of abuse. According to the scoring formula, out of 30 respondents, 8 are moderately aware and 22 are aware of legal protections. Of the 8 respondents who are moderately aware of protection, all report some type of abuse, and out of 22 women who have knowledge of legal protections, 12 are victims of some type of abuses.

Sweepers: Out of 50 sweepers, all respondents are less legally aware and all are victims of some type of abuses. 
Table 1. Profession and legal awareness.

\begin{tabular}{ccccc}
\hline Score & & $\mathbf{0 ~ - ~ 5 0}$ & $\mathbf{5 0 - 1 0 0}$ & $\mathbf{1 0 0}$ and above \\
\hline Profession & Total & - & - & - \\
College teachers & 50 & - & 03 & 47 \\
School teachers & 70 & - & 06 & 64 \\
Clerks & 30 & - & 08 & 22 \\
Sweepers & 50 & 50 & - & - \\
\hline
\end{tabular}

Table 2. Legal awareness by profession including mean, standard deviation, coefficient of variation and range of profession and legal awareness.

\begin{tabular}{ccccc}
\hline Profession & Mean & Standard deviation & Coefficient of variation & Range \\
\hline College teachers & 122 & 15.73 & 12.89 & 34 \\
School teachers & 120.7 & 16.66 & 13.80 & 35 \\
Clerks & 111.66 & 22.11 & 19.81 & 43 \\
Sweepers & 25 & 0 & 0 & 05 \\
\hline
\end{tabular}

Table 3. Relationship between legal awareness and number of abuse.

\begin{tabular}{cccccccccc}
\hline Profession & $\begin{array}{c}\text { Total No. of } \\
\text { women }\end{array}$ & Total No. of victims & $0-50$ & No. of victims & $50-100$ & No. of victims & 100 above & No. of victims & (r) \\
\hline College teachers & 50 & 8 & 0 & 0 & 3 & 2 & 47 & 6 & 0.96 \\
School teachers & 70 & 30 & 0 & 0 & 6 & 5 & 64 & 25 & 0.99 \\
Clerks & 30 & 20 & 0 & 0 & 8 & 8 & 22 & 12 & 0.94 \\
Sweepers & 50 & 50 & 50 & 50 & 0 & 0 & 0 & 0 & 1.00 \\
\hline
\end{tabular}

\subsection{Education and Legal Awareness}

Table 4 shows the relationship between level of education and legal awareness. Out of 60 post graduate women, 3 are moderately aware and 57 women are aware. Among 60 graduate women, 6 are moderately aware and 54 are aware.

This table shows that out of 30 women, who are matriculates, but not graduates, 8 respondents are moderately aware and 22 are aware. Nevertheless, all 50 respondents who have education less than matric are less aware.

Table 5 shows the average, standard deviation, coefficient of variation and range of education and legal awareness. The average legal awareness score of Post graduate is 122.5 , Graduate is 120, more than matric, but not graduate, is 111.66 and less than matric is 25.The standard deviation of different educational groups are 10.89, 15.00, 22.11 and 00 of post graduate, graduate , more than matric but not graduate and less than matric respectively.

As the mean is different for different groups, the coefficient of variation is used for comparing the data. The results show the coefficient of variation is 8.89 for post graduate women, 12.5 for graduate and 19.8 for more than matric but less than graduate.

As the standard deviation is zero for less than matric women, so the coefficient of variation is also zero. The range is 36, 37, 43, 05 for post graduate, graduate, more than matric, but not graduate, and less than matric women respectively.

\subsection{Legal Awareness and Number of Abuse in Different Educational Groups}

Table 6 shows the score of legal awareness among women of different educational groups and the number of victims in different awareness range.

Post graduate: There are 60 women whose educational qualification is either post graduate or more than that. Out of these 60 respondents, 10 are the victims of any type of abuse. Scoring shows out of 60, 4 are moderately aware and 56 are aware. The table shows out of 4 moderately aware women, 3 are victims; and out of 56 aware 
Table 4. Education and legal awareness.

\begin{tabular}{ccccc}
\hline Education & Score total & $0-50$ & $50-100$ & 100 and above \\
\hline Post graduate & 60 & - & 03 & 57 \\
Graduate & 60 & - & 06 & 54 \\
More than matric but not graduate & 30 & - & 08 & - \\
Less than matric & 50 & 50 & - & - \\
\hline
\end{tabular}

Table 5. Mean, standard deviation, coefficient of variation and range of education and legal awareness.

\begin{tabular}{ccccc|}
\hline Education & Mean & Standard deviation & Coefficient of variation & Range \\
\hline Post graduate & 122.5 & 10.89 & 8.89 & 36 \\
Graduate & 120 & 15.00 & 12.5 & 37 \\
More than matric but not graduate & 111.66 & 22.11 & 19.81 & 43 \\
Less than matric & 25 & 0 & 0 & 05 \\
\hline
\end{tabular}

Table 6. Relationship between legal awareness and number of abuse in different educational groups.

\begin{tabular}{cccccccccc}
\hline Education & $\begin{array}{c}\text { Total No. of } \\
\text { women }\end{array}$ & $\begin{array}{c}\text { Total No. of } \\
\text { Victims }\end{array}$ & 0 - 50 & $\begin{array}{c}\text { No. of } \\
\text { victims }\end{array}$ & $50-100$ & $\begin{array}{c}\text { No. of } \\
\text { victims }\end{array}$ & 100 above & $\begin{array}{c}\text { No. of } \\
\text { victims }\end{array}$ & $\begin{array}{c}\text { (r) } \\
\text { Post graduate }\end{array}$ \\
$\quad 60$ & 10 & 0 & 0 & 4 & 3 & 56 & 7 & 0.92 \\
$\quad \begin{array}{c}\text { Graduate } \\
\text { More than matric but not } \\
\quad \begin{array}{c}\text { graduate } \\
\text { Less than matric }\end{array}\end{array}$ & 60 & 29 & 0 & 0 & 5 & 4 & 55 & 25 & 0.99 \\
\hline
\end{tabular}

respondents, 7 are victims of any type of harassment.

Graduate: Out of 60 women whose educational level is graduation, 29 are victims of any type of abuse. According to the scoring out of 60, 5 women are moderately aware and 55 are aware of legal protections. Among 5 moderately aware women, 4 are victims of abuses, Of 55 aware women, 25 are victims of any type of abuse.

More than matriculate, but less than graduate: In this category out of 30 respondents, 20 are exposed to any type of harassment. Among 30 respondents, 8 women are moderately aware and 22 are aware of legal protections. Among 8 moderately aware 8 and 22 aware women, 12 are victims of any type of abuse.

In the category of respondents who reported having less than matriculate education, 50 out of 50 women are less legally aware; and all are victims of any kind of abuse.

\subsection{Income and Legal Awareness}

Table 7 reveals the level of legal awareness among women of different income groups.

Out of 50 women whose income level below Rs.5000/- All 50 are less legally aware.

Among the 30 women whose income level is between Rs.5000/- to Rs.10,000/-, 8 are moderately aware and 22 are aware.

70 women whose income are between Rs.10,000/- to Rs.15,000/-, 6 are moderately aware and 64 are aware among them.

3 women are moderately aware and 47 are aware among 50 women whose income level is more than Rs.15,000/-.

Table 8 reveals the average number of legal awareness score of women whose income is less than Rs.5000/is 25 and standard deviation is 0. Women having income of Rs.5000/- to Rs.10,000/- the mean number is 111.66 and standard deviation is 22.11. The average number is 120.7 and standard deviation 16.66 of women whose income is between Rs.10,000/- to Rs.15,000/-. Women whose income level is above Rs.15,000/- the average legal awareness score is 122 and standard deviation is 15.73 .

As the mean of different group is different the coefficient of variation shows the comparisons among different groups. The coefficient of variation is 0 for women whose income is less Rs.5000/- as their standard deviation 
Table 7. Income and legal awareness.

\begin{tabular}{ccccc}
\hline Income & Score Total & $0-50$ & $50-100$ & 100 and above \\
\hline Less than Rs.5000/- & 50 & 50 & 00 & 00 \\
Rs.5000/- to Rs.10,000/- & 30 & 00 & 08 & 22 \\
Rs.10,000 to Rs.15,000/- & 70 & 00 & 06 & 64 \\
Rs.15000 and above & 50 & 00 & 03 & 47 \\
\hline
\end{tabular}

Table 8. Mean, standard deviation, coefficient of variation and range of income and legal awareness.

\begin{tabular}{ccccc}
\hline Income & Mean & Standard deviation & Coefficient of variation & Range \\
\hline Less than Rs.5000/- & 25 & 0 & 0 & 05 \\
Rs.5000/- to Rs.10,000/- & 111.66 & 22.11 & 19.81 & 43 \\
Rs.10,000 to Rs.15,000/- & 120.7 & 16.66 & 13.8 & 35 \\
Rs.15000 and above & 122 & 15.73 & 12.89 & 34 \\
\hline
\end{tabular}

is 0 . The coefficient of variation 19.81 for women having income between Rs.5000/- to Rs.10,000/-, 13.80 of women having income between Rs.10,000/- to Rs.15,000/- and 12.89 for women having income above Rs.15,000/-. The range for women whose income is less than Rs.5000/- is 5, 43 for income group between Rs.5000/- to Rs.10,000/-, 35 for income group Rs.10,000/- to Rs.15,000/- and 34 for Rs.15,000/- and above.

\subsection{Legal Awareness and Number of Abuses in Different Income Groups}

Income below Rs.5000/-: In this category out of 50 women all are less legally aware and are victims of any type of abuse.

Income between Rs.5000/- to Rs.10,000/-: In this income group out of 30 women 20 are exposed to any type of abuse. Out of this 30 women 8 are moderately aware and 22 are aware. Among 8 moderately aware 8 are victims and out of 22 aware women 12 are victims.

Income between Rs.10,000/- to Rs.15,000/-: Among 70 women belonging to this income group, 30 are victims of any type of abuse. Out of 70, 6 are moderately aware and 64 are aware women. Out of 6 moderately aware women 5 are victims and 64 aware women 25 are victims (Table 9).

Income above Rs.15,000/-: 50 women are present in this category out of 50, 8 are victims of any type of abuse. 3 women out of 50 are moderately aware and 47 are aware. Among 3 moderately aware 2 are victims and 47 aware women 6 are victims.

\section{Analysis and Discussion}

This study reveals that there is a positive relationship between professions, education, income and level of legal awareness among women against violence and abuse. The higher the income, education and profession, the better is the level of legal awareness. Women from higher educational groups like college teachers, school teachers and clerks have some idea about Acts related to dowry, divorce and sexual harassment at workplace. Yet, the Protection of Women from Domestic Violence Act is less known among these women.

Sweepers have no idea about any Act, except the one referring to Dowry.

Every day the front pages of newspapers are wedded with news related to women being tortured or murdered because of dowries. Televisions also regularly publicize information about the Dowry Act. Thus, women from all educated categories know about The Dowry Act, although the minute details of the Act are not known to any category of respondent in this study

Many women with better education know that married couples can be separated from each other with the help of Divorce Act. However, they are not clear about the grounds upon which divorce can be taken.

A study conducted by H.S. Krupalini and Vighnesh, N. Bhat (2003) in three different Universities of Karnataka shows that $12 \%$ of the rural undergraduate respondents are aware of different Acts of Protection Against Violence Against Women; 32.6\% are unaware of any measure; and 5.3\% are aware of legal provisions only partially [11]. Our study demonstrated that education is one of the most important factors influencing the level of awareness of legal rights among women. Choudhry pointed out that awareness of legal rights among women 
Table 9. Relationship between legal awareness and number of abuse in different income groups.

\begin{tabular}{cccccccccc}
\hline Income & $\begin{array}{c}\text { Total No. of } \\
\text { women }\end{array}$ & $\begin{array}{c}\text { Total No. } \\
\text { of Victims }\end{array}$ & $0-50$ & $\begin{array}{c}\text { No. of } \\
\text { victims }\end{array}$ & 50 - 100 & $\begin{array}{c}\text { No. of } \\
\text { victims }\end{array}$ & $\begin{array}{c}100 \\
\text { above }\end{array}$ & $\begin{array}{c}\text { No. of } \\
\text { victims }\end{array}$ & $\begin{array}{c}\text { (r) } \\
\text { Less than Rs.5000/- }\end{array}$ \\
50 & 50 & 50 & 50 & 0 & 0 & 0 & 0 & 1.00 \\
Rs.5000/- to Rs.10,000/- & 30 & 20 & 0 & 0 & 8 & 8 & 22 & 12 & 0.94 \\
Rs.10,000 to Rs.15,000/- & 70 & 30 & 0 & 0 & 6 & 5 & 64 & 25 & 0.99 \\
Rs.15000 and above & 50 & 8 & 0 & 0 & 3 & 2 & 47 & 06 & 0.96 \\
\hline
\end{tabular}

comes with education. However, she has also noted that education alone does not necessarily equip women with comprehensive information about existing legal provisions on various aspects of life. Further, she stated that only those legal rights which affect the immediate life of a woman are better known. Nevertheless, awareness, whether partial or full, as shown by the responses in Choudhary's study indicates that educated women of today are more conscious of their well-being as such they are keen to raise their social status [12].

Women's groups have dubbed the Protection of Women from Domestic Violence (PWDV) Act as a path breaking law, not merely because it is an independent civil law that identifies violence against women in the shared household as "domestic violence", but also because it provides women the right to reside in the shared household and protects women in non-matrimonial relationships. Despite the fact that the Domestic Violence Act was formed to safeguard women from violence on the domestic front and to bring justice to the victims, women in India continue to be victims of domestic violence without obtaining justice. After 15 years since the Protection of Women from Domestic Violence Act was passed, it still continues to remain legal in the legal domain and thus restricts its use to lawyers and civil society organizations who working on women's empowerment [13].

In a study conducted in Italy, Kenya, Mexico, Philippines, Tunisia, South Africa, Brazil, Fiji and India, lack of implementation of existing constitutional and statutory guarantees was a major problem affecting the agriculture-related rights of rural women. The lack of implementations is caused by many factors, but, primarily by the existence of socio-cultural attitudes consistent with formal legislation. Other factors effecting implementation (negative or positive) are more directly related to the legal system. Why are certain laws not so effective? Ogato (2013) has rightly stated that on a macro-political level most governing bodies are dominated by men and legislative and judicial decisions, therefore, often lack a gender perspective and do not represent women's interests. Legal reform can be a significant strategy for empowering women and girls and safeguarding their rights [6] [14]. Razvidzo (2007) encourages governments to strengthen legal frameworks that promote the rights of women and designate all international and regional instruments for women's rights [15].

This study also reveals that the level of legal awareness is high among those women who are better educated, have a good income, and who have higher level professions are less prone to victimization [16]. That means there is an inverse relationship between levels of legal awareness with likelihood of victimization.

This may be due to 1) educated women are self-conscious. They respect their self and try to know about a law that protects them, 2) educated women are more aware about their rights, 3) education always broadens the sphere of awareness. Bilal S (2014) also suggests that rural women are less aware of legal rights as the illiteracy rate in high. They also do not have sufficient resources to utilize these laws [17].

This study did not include any Muslim women as Muslim Law is different. Though Muslim Law does not takes precedence over constitutional law in India, Cases like Saha Bano (1985 AIR 945) has challenged the Muslim Personal Law that lead to debate in the constitution and resulted in the passing of the Muslim Women Protection (Protection on right to Divorce) in 1986. However because of secular characteristic of India, Muslim practice their own religious belief regulated sometime by Muslim Personal Law board and have fundamental difference in religious prospective. Nonetheless the prospects for Muslim women in the wake of the Beijing Conference do not seem particularly bright, because of the rejection or non-compliance of several Muslim and non-Muslim countries with the principle of equality between men and women in the family [18]. Kazi also stated that law by itself cannot be the sole determinant of Muslim Women's status in Indian society. The socio-economic status of Indian Muslim women mandates attention not only because it is a marker of women's progress, but it is difficult to institute legal reforms without simultaneous progress in Muslim women's educational status and economic autonomy [19].

The report published by Virtual Knowledge Centre to End Violence against Women and Girls by U.N. shows 
that NGO's in many countries have taken the initiative to make women aware of their legal rights and exercising these laws, i.e. to restrict trafficking among women, Colombia has designed an awareness and prevention campaign that provided all Colombians with a hotline that provides job information and within one year the calls increased by 400\%. In Turkey, concentration was placed on the most disadvantage women and girls with a programme combating Domestic Violence Against Women: National Action Plan-2007-2010 This programme aimed to raise awareness and change attitudes and behaviors. Interventions should involve both providing information on laws on violence against women and how women who are victims of violence can more easily obtain assistance for themselves. For example, the Women's Rights Awareness Programme (WRAP) in Kenya, provides information in a publication called Know Your Rights, A Best Practical Guide on Gender Based Violence on a Service Directory, among other publications which are distributed free of charges [20].

Though this study does not include specific questions related to respondents' suggestions for improving awareness of laws and actions to protect women, during the interviews, women expressed their opinions as to why laws are not so effective. Their reported reasons include: 1) delays in legal procedure, legal cases take a long period to be solved. 2) Police are not well equipped with either understanding the laws or how to implement them. 3) The long established social and cultural tradition of Indian life perpetuates treatment of women contemptuously by policeman and 4) legal machinery is not sensitized towards problems of women. Saxena S. (1999) stated that knowledge about legal enactment is very scant, not only amongst the educated women like executive, teachers and office workers but also amongst the men in these positions [21]. The majority of the subjects in our study showed that both men and women opined that the whole subject of law is complicated and too vast to be understood. Yadav, M (2007) also stated that people have knowledge about different laws, but are ignorant about their use [22].

\section{Conclusions}

In view of the seriousness of violence against women and domestic violence, as a breach of human rights and public health concern, it is critical that an agreement on definitions and research tools be reached. The antiwomen's backlash spurred by the family violence approach may lead to the continuation of practices that put women's health and safety in jeopardy. For laws and policies to be effective, they must be based on grounded research and a compelling and reliable database that is context-specific and nationally and internationally comparable as well as guided by gender-sensitive epistemic framework.

Violence Against Women is a global phenomenon that is rooted in the unequal balance of power between women and men, resulting in women suffering severe forms of physical, emotional, sexual and economic harm and abuse. Laws and policies must reflect this recognition. International tools such as the Millennium Development Goals and other human rights and other human rights instruments, particularly CEDAN and the Beijing Platform for Action, should continue to be the basis of social advocacy, law-making and policy-generation for Violence Against Women. Sexual literacy, legal awareness among women and gender awareness among people involved in law enforcement must be given special attention. Equally important in efforts to prevent violence and abuse against women is greater education for girls and a ban on early marriage. As domestic violence takes place in the home and is often justified by patriarchal biases that stipulate that women should be demure, dependent and submissive, the fallacy of harmonious Asian family must be exposed. Wieringa, S. and Maznal Mohammed (2013) and UNDP also suggested the following points to strengthen the legal system: 1) provide easier and greater access to justice for victims of domestic violence and abuse; 2) improve public confidence in the justice system; 3) develop programme oversight and strategic planning in the justice sector; 4) strengthen management system and procedures; 5) use local language in all media publicity about laws and ways to obtain services and justice for women who are victims of violence and abuse; 6) establish a progressive budget for the justice system; 7) routine training for the public defender's office and the police in and legal education and how to respond effectively and sensitively to a victim in need of assistance [23] [24].

As expressed by the respondents in this study, speedy judgment, honestly in case of lawyers and judges and the attitudinal and behavioral change of both men and women are essential to strengthen the legal system.

\section{Acknowledgements}

The author is thankful to Prof. Braja Kishori Mishra, Sambalpur University for her kind help in data analysis and documentation. 


\section{References}

[1] Jethi, J. (2007) Commentary on Protection of Women from Domestic Violence Act-2005. Law House, Cuttack, Odisha, $1-37$.

[2] Syed, S.A.J. (2004) Women in India, Legal and Human Rights. Centre for Professional Development in Higher Education and Women's Studies and Development Centre. University of Delhi, 1-24.

[3] Baden, S. and Oxaal, Z. (1997) Gender and Development Definitions, Approaches and Implications for Policy. BRIDGE (Development-Gender) Brigton, Institute of Development Studies, Report No-40, 1-32.

[4] Baden, S. and Reeves, H. (2000) Gender and Development. Concepts and Definition, BRIDGE (Development-Gender), Briton, Institute of Development Studies, 23-65.

[5] Dejene, A. (2003) Integrated Natural Resources Management to Enhance Food Security; the Case of Community Based Approaches in Ethiopia. Rome, Food and Agricultural Organization of United Nations, Report 16, 11-30.

[6] Ogato, G.S. (2013) The Quest for Gender Equity and Women's Empowerment in Least Developed Countries, Policy and Strategy Implication for Achieving Millennium Development Goals in Ethiopia. International Journal of Sociology and Anthropology, 5, 358-372. http://dx.doi.org/10.5897/IJSA2013.0454

[7] Staff Reporter (2013) Call for Legal Awareness among Women. The Hindu, March 15, 4-6.

[8] Rao, A. (2008) Stress and Health Implications of Domestic Violence in Women in Difficult Circumstances. NIPCCD, New Delhi. Summaries of Research, 65, 52-53.

[9] Mitra, N. (2008) Domestic Violence as a Public Issue: A Review Response in Women in Difficult Circumstances. NIPCCD, New Delhi. Summaries of Research, 63, 13-40.

[10] Staff Reporter (2010) Legal Issues and Violence against Women in Domestic Front. The Hindu, September 27, 4-5.

[11] Krupalini, H.S. and Bhat, V.N. (2003) Women in Developing Country-Aspiration and Perception. APH Publishing, New Delhi, 170-180.

[12] Choudhary, P.K. (1988) Changing Values among Young Women. Amar Prakasan, New Delhi, 166-167.

[13] Dhar, A. (2013) Torment within Four walls. The Hindu, January 29, 6-7.

[14] UNICEF (2006) The State of the World Children 2007: Women and Children. The Double Divided of Gender Equality. Report 3, United Nation Children Fund, New Delhi, 23-54.

[15] Ruzvidzo, T.C. (2007) Gender Wet. Economic Commission for Africa, Addis Ababa, 358-372.

[16] Jase, J. (2014) Legal Awareness of Academic professionals-A Case Study of UGCNET. International Research Journal of Social Sciences, 3, 22-26.

[17] Bilal, S., Singh, R. and Singh, J. (2014) Awareness and Exercise of Legal Rights among Working and Non-Working Women in Punjab. Educational Confab, 3, 20-27.

[18] Mayar, A.N. (1995) Rhetorical Strategies and Official Policies on Women’s Rights: The Merits and Drawbacks of the New World Hypocrisy. In: Afkhami, M., Ed., Faith and Freedom: Women Human Right in World, Tauris, London, 104-132.

[19] Kazi, S. (1999) Muslim Women in India. Minority Rights Group International, London, 19-29.

[20] LUCCACO (2012) UN Women—United Nations Entity for Gender Equality and Empowerment of Women. Report 1, 23-24.

[21] Saxena, S. (1999) Crime against Women and Protective Laws. Deep and Deep Publication, New Delhi, 122-227.

[22] Yadav, M. (2007) Sexual Harassment of Women current Scenario of Indian Hospitals. Journal of JIAFM, 29, $122-143$.

[23] Wieringa, S. and Maznah, M. (2013) Family Ambiguity and Domestic Violence in Asia Concept Law and Process. Academic Bess, Sussex, 20-25.

[24] UNDP (2011) Justice System Strengthing Programme-Mid Team Evaluation Report. UN Agency, 123-145. 